\title{
2: 74693515-74696318
}

National Cancer Institute

\section{Source}

National Cancer Institute. 2: 74693515-74696318. NCI Thesaurus. Code C42144.

Physical location of DOK1_Gene 